\title{
Do Learners Fear More than Fear Itself: The Role of Fear in Law Students Educational Experiences
}

\author{
Jeffrey Perrin ${ }^{1}$, Jennifer O’Neil ${ }^{1}$, Ashley Grimes ${ }^{1} \&$ Laura Bryson $^{1}$ \\ ${ }^{1}$ Lesley University, Cambridge, Massachusetts, United States of America \\ Correspondence: Jeffrey Perrin, Division of Psychology and Applied Therapies Division, Lesley University, Cambridge, \\ MA, 02138, United States of America
}

Received: November 23, 2013 Accepted: December 6, 2013 Online Published: January 24, 2014

doi:10.11114/jets.v2i2.290

URL: http://dx.doi.org/10.11114/jets.v2i2.290

\begin{abstract}
While previous research has examined the various relationships between fear and learning in K-12 academic settings, the relationship is surprisingly unexplored amongst law students. Using a descriptive qualitative approach, we examine the role fear plays in law students' learning experiences. Through a series of semi-structured interviews a few areas of interest emerged including: fears related to disappointing family members and professors, as well as fears of peer judgment from classmates. The findings of this study demonstrate the unique relationship between the type of fear and how it influences academic motivation within this sample of law students. Based on our findings, we propose suggestions for future research that addresses the potentially detrimental effect of peer judgment on graduate students' academic motivation.
\end{abstract}

Keywords: fear, graduate students, disappointing others, peer judgment

\section{Introduction}

\subsection{The Relationship between Fear and Learning}

The relationship between fear and learning is complex and surprisingly unexplored in the fields of legal education and psychology. The core of the argument focuses on whether fear impedes or promotes learning. John Dewey claimed that fear stops engagement and therefore growth (Dewey, 1984). He associated fear with moments that are non-educative and interest with moments that are educative. On the contrary, Jean- Jacque Rousseau postulates that we should "teach our children to preserve himself as a man, to bear the blows of fate, to brave opulence and poverty, to live, if he has to in freezing Iceland or on Malta's burning rocks" (Rousseau, 1762/1979, p. 42). Rousseau's emphasized the necessity of protecting learners while simultaneously exposing them to situations that might be frightening.

Traditionally, the fear and learning literature has focused on middle school, high school, and college age students (Covington \& Omelich, 1979; Eme \& Lawrence, 1976; Jackson, 2010; Martin, 2011; Schouwenburg, 1991; Sprinkle, Hunt, Simonds \& Comadena, 2006). There is little information regarding fears in graduate students. We believe it is important to continue to study this dynamic at the graduate level for several reasons. First, social dynamics change as students' progress further along their educational path. They are more likely to find themselves in direct competition with other students who have similar academic and career goals. The dynamic of this change can be quite profound and is worth investigating. Second, the influence of teachers and parents changes as students start to identify specific career choices. They may begin to see these individuals as allies in their pursuits as opposed to adversaries. Therefore it is important to consider how these relationships influence student fears as they begin their professional lives. Finally, emotion is an important component of the learning process. Although certain fears related to learning are debilitating there may be instances when fear motivates individuals to make a greater effort. It is important to explore when certain fears are debilitating and when these fears may be advantageous.

In order to investigate the relationship between fear and learning amongst law students, we think it is critical to listen to individual learning stories while considering social and cultural context. Under what educational circumstances were learners most fearful? How did this fear impact their motivation? Under what conditions is fear beneficial? Under what conditions is fear detrimental? Hearing learners' educational experiences will start to shed light on these relationships and, in this case, provide a clearer picture of how the demonstration of fear impacts learning experiences at the graduate school level. 


\subsection{The Role of Emotion in Learning}

Without question, emotions are a core component of the human experience. Our emotions can assist the way information is received, retained, interpreted, and used (Hochschild, 1983; Milton, 2002). Contrastingly, they also may cause severe disruptions in judgment (Forgas \& Bower, 1987), decision-making (Isen, 1993), memory, (Bower, 1981) and behavior (Berkowitz, Jaffee, Jo, \& Trocolli, 1999). There is a reciprocal relationship between thought and emotion that counters the traditional view that emotions hinder rational thought (Barbalet, 1998).

In order for learning to take place, emotions are necessary and the knowledge that is acquired through learning generates emotions. According to Milton (2002), "people do indeed come to love, enjoy, or fear things in the process of getting to know them; they also get to know them as a result of loving, enjoying, hating or fearing them" (p.66). The intricacy of the relationship makes it difficult to determine how individuals develop particular emotions for specific places, things, or people. The demonstration of particular emotions can only be understood within the complete context of the individual's experience in specific environments.

Although test anxiety is a frequently explored topic in education research (Putwain, 2008; Putwain, 2009) other sorts of anxieties or fears related to learning are relatively unexplored. The bulk of the research on fear and learning investigates fear of failure (Belanger, Lafreniere, Vallerand \& Kruglanksi, 2012; Covington \& Omelich, 1979; Schouwenburg, 1992; Williams, Jamieson \& Hollingsworth, 2008; Martin \& Marsh, 2003). Reaserch done on traditional undergaduates shows that fear of failure is often associated with "...high anxiety, underachievement, reduced resilience..." and in some cases may lead students "to learned helplessness"(Martin \& Marsh, 2003, p. 31). Covington and Teele (1996) found that fears of failure may manifest in procrastination, impossibly high goals, and nonperformance. These strategies make academic success highly unobtainable.

\subsection{The Role of Emotion in Legal Education}

In a qualitative self-report study, Elkins (1985) found that first year law students experienced an array of emotions including: exhilaration, alienation, frustration, boredom, depression, and despair, during their first semester of law school. Elkins (1985) emphasized the importance of investigating students' emotional experience in order to fully understand the intricacies of legal education. In a similar qualitative study conducted by Reifman, McIntosh and Ellsworth (2000), law students were asked to anonymously report on their emotional experiences while in school. Humiliation, lack of control, and isolation were amongst the various emotional themes identified by the researchers. The stress and anxiety levels of of students at the end of their first and third years of law school was similar to those individuals going through a major life trauma (e.g. death of a spouse). The researchers found that several of these emotions were instigated by their law school experience as opposed to law school attacting students with a proclivity towards this side of the emotional spectrum. In addition, Hess (2002) documented the many negative effects of law school on students including the fact that students lose self- confidence and experience high psychological anguish as well as substance abuse due to these psychological issues. Lacombe, Tumbaga, Malkin, Nicholson and Tokatlidis (2013) found that high levels of stress amongst law students may lead to academically self-destructice behavior, such as skipping classes. Furthermore, in a study specifically addressing fear, Beck and Burns (1979) cited fear of failure as being connected to the intense competition that happens while completing a law program.

Although researchers have reported several emotions related to law students' experiences, we focus specifically on the role of fear in law students' educational experiences. We'd like to see whether there are additional fears, beyond fear of failure, related to legal education that might be contributing to law students' experience.

\subsection{An Exploratory Qualitative Approach}

This paper offers an exploratory qualitative insight into the experiences of law students' reports of fear as it relates to learning. For the purposes of this paper we used Rachman's (1978) definition of fear which means that "fear refers to feelings of apprehension about tangible and predominately realistic dangers" (p. 6). The central research questions that guided this study were: what are the sources of law students' fears related to learning and how do fearful responses impact academic motivation. We explored this topic through a series of interviews with law students.

\section{Method}

We used a descriptive qualitative approach to investigate participants' experience of fearful thoughts in educational settings and their subsequent impact on motivation and perceptions of overall learning. The University Institutional Review Board approved the study design and questions.

\subsection{Recruitment}

The recruitment criteria required participants to be over the age of 18 and currently enrolled in a graduate law school program. We placed flyers around a local graduate law school campus and posted a recruitment advertisement in the 
school paper. Interested participants were instructed to contact a member of the research team via email to set up an interview time.

\subsection{Participants}

We interviewed 12 adult participants $($ Male $=7$, Female $=5$ ) from a law school located in New England. Participants ranged from 24-28 years old, had at least a Bachelor's degree, and were currently enrolled in graduate law school.

\subsection{Data Collection}

Members of the research team conducted face-to-face semi-structured interviews on the campus of the research sponsoring institution. Interviews lasted approximately 60-75 minutes and were guided by an interview schedule. Members of the research team, following an extensive review of relevant literature, designed the interview schedule. We used open-ended questions that allowed participants to reflect on their educational experiences, thoughts of fear/anxiety related to these experiences, as well as the perceived impact of these thoughts on their motivation and overall perceived learning. Specifically, participants were asked about times when different types of fear might have positively or negatively influenced their motivation or ability to learn. Once the interview was completed, the participants were asked if they had any further questions. They were handed a debriefing form that provided them with additional information about the study. Finally, they were compensated with $\$ 20$ and escorted out from the interview session. All interviews were audio taped and transcribed verbatim by members of the research team.

\section{Results}

We conducted a thematic content analysis of the interview data (Thorne, 2008). This approach is most suitable for small-scale, qualitative investigations that seek to convey themes and patterns to generate interpretive descriptions (Thorne, 2008). The data were analyzed inductively for emerging themes across the interviews. First, the four researchers independently open coded the interview transcripts and created tentative initial coding categories. Then the research team met and compared their coding categories. Next, following an extensive discussion, we refined and grouped our independent codes into a focused coding structure that was applied to the whole data set (Glaser \& Strauss, 1967). All authors agreed on the final set of code topics.

\subsection{Family}

Several participants mentioned fear of disappointing family members when discussing the source of their fears. We identified two specific circumstances that were associated with participants' reports of fear related to disappointing family members: high achieving parents and first in family to attend graduate school.

In several instances, participants compared their own academic success to the successes of their parents. Several interviewees identified a need to achieve the same results or better. Participant \#3 notes the motivating component of having a successful father and comparing his accomplishments to his father's:

"As I mentioned before I think, my dad's a lawyer. He's quite successful. I mean there's an aspect of wanting to do well and not embarrass myself" (Participant \#3).

Similarly, another Interviewee \#7 discussed the success of his father and the internal pressure to do as well as he did:

"I never wanted to let him down. And that was one thing that motivated me through high school. He was the salutatorian of his class, so, I thought if he was salutatorian I better at least be that. Then he went to college and got one B in college and I thought well he got Bs I better get one of them. I don't think if I hadn't gotten more he would have been disappointed but I think it was an internal thing" (Participant \#7).

Not all participants' parents or relatives achieved great academic success. Some participants felt a pressure to make the most out of their educational opportunities due to the fact that their relatives didn't have similar educational opportunities.

"My grandparents and some family members didn't have high levels of education. They push for education a lot. I'm from the south. When my grandparents grew up they couldn't really access education. For them it's always been something that they want to see more of" (Participant \#6).

In some instances the pressure was more explicit. Participant \#11 discusses the pressures from her family that emigrated from Russia:

"I'm the first one from my family to ever go to law school. As I mentioned before we are immigrants from Russia and it is a pretty big deal in my family. They all expected me to do really great. Everyone just thinks I'm really smart. It's hard for them to understand that everyone is like that at law school. I guess they had really high expectations for me. It is hard. I am basically afraid that I'm not going to meet those expectations" (Participant \#11). 


\subsection{Student/Professor Relationship}

Many students feel an added need to perform well in order to have teachers think highly of them. Whereas students did not report a desire to impress fellow classmates in classroom discussions, they were driven to please teachers.

"I felt generally pretty motivated to get good grades to impress my teachers" (Participant \#16).

The need to perform well seemed to be particularly salient when students believed that teachers had a favorable impression of them.

"I had some teachers that you know they thought highly of me and so of course I wanted to do well in those classes especially to reinforce that idea" (Participant \#6).

The increase in motivation was positively correlated with how much the student respected or liked the professor.

"I had a lot of help from professors who had given me their time to help me with my project and that motivated me because I wanted to do good work for them. I wanted them to be happy with my work more than me objectively caring about it" (Participant \#5).

Participant \#15 highlights how she feels upset at herself when she thinks she disappointed her professors:

"I feel that way a lot with my professors. I study harder for professors that I like. The feeling that I might disappoint them is sort of a very powerful counter idea to that. Because I don't want to disappoint them I work extra hard. It makes me upset when I think I may have done something to disappoint them. I guess to connect that to my learning experience it makes me work harder" (Participant \#15).

\subsection{Peer Judgment}

The fear of peer judgment was frequently mentioned as a demotivating factor in participants' learning experiences. At times students were hesitant to participate in classroom discuss (by expressing opinion, asking questions) due to fear of their peers' response. In particular one female participant noted her tentativeness to discuss material in class that she was very passionate about due to fear of how her comments would be received:

"I felt this more first semester of law school than this semester, but there are definitely things that got me very worked up about the material we were covering in class or the topics we would go into. Topics that just made me really angry that I didn't raise in class. I didn't because it wouldn't be received well. I definitely have that fear about talking about it openly" (Participant \#15).

In addition to a fear about how her comments would be received, she also discussed the more general fear of sounding unintelligent or irrelevant. This fear manifested in participation withdrawal:

"Again first semester, this is just when I was afraid of law school in general. There were definitely moments where I had something I wanted to say in class, but didn't raise my hand either out of fear that what I would say would just sound stupid or irrelevant or people would judge me for it. Times when I would say it, I would just feel stupid like I said something irrelevant and that people were judging me. So, whether or not I spoke up or not, that fear of social rejection was ever present" (Participant \#15).

Other interviewees discussed social pressures around over-participating in class discussions. Participants \#3 discusses the hazards of speaking too much in class:

"Some people don't talk because there's a bit of a social pressure for talking too much- it's seen as showing off. But some people are just nervous about it and don't speak up" (Participant \#3).

Related to this idea, Participant \#1 highlighted the dangers of appearing too engaged in one's work:

"Being engaged in what you're doing, doing you're work, and looking like you enjoy being there is not cool or accepted" (Participant \#1).

Contrary to most participants, some participants found competitiveness, measured by class rankings and grades, in law school to be motivating. Participants didn't discuss this within the context of classroom discussion, rather, they discussed how this impacted study habits.

"In law school again, it's a lot of the pressure, the social pressure, to stay out of the pack or fall behind and law students are always comparing themselves to one another. And so there is a lot of social pressure in law school, which leads to a lot of extra studying over studying maybe. And also a lot of strange and unnecessary study habits I guess. I don't know, but it is less self-motivated and the learning experience is kind of dictated by the terms of kind of the group. It's a lot of groupthink" (Participant \#9).

Participant \#1 discussed how fear can be motivating because students want to avoid being embarrassed in class. Specifically, he addresses being called on in class and appearing unprepared. 
"It is motivating by fear rather than enthusiasm. But honestly I think it's the best motivator in terms of if you've got this fear of being called on to answer a question and you're unprepared and everyone else is like 'oh god you are such an idiot'. I think that is definitely less of a positive motivation then being truly interested in something but is a motivation nonetheless" (Participant \#1).

\section{Discussion}

The aim of this present study was to investigate sources of graduate students' fears related to learning and to explore the relationship between fear and academic motivation. We looked at this topic through a series of interviews with graduate students. The fear of disappointing others (parents, extended relatives, professors) was a concern for interviewees. The circumstances under which participants voiced their fear of disappointing others differed. While some participants discussed the fear of disappointing highly educated and successful parents, others highlighted the fear of letting down family members who did not attend graduate school. Regardless of the catalyst, participants frequently expressed a fear of disappointing others. According to Schimmack \& Diener (1997) disappointment is the third most frequently experienced emotion following anxiety and anger. Bell (1985) defines disappointment as "a psychological reaction to an outcome that does not match up against an expectation" (p.1). Similarly, Ortony, Clore, and Collins (1988) define disappointment as being "displeased about the disconfirmation of the prospect of a desirable event" (p. 110). Simply, disappointment occurs when expected outcomes are not met.

Participants did not report "feeling disappointed", rather they reported a fear of disappointing others. The anticipation of this emotion seems to motivate subjects to avoid it from occurring. Often times the anticipation of future emotions is related to behavioral choices (Fridja, 1986). In this study, several interviewees alluded to being motivated by thoughts of disappointing others.

Van Dijk and Zeelenberg (2002) differentiate between outcome-related disappointment and person-related disappointment in appraisal patterns and response types. Outcome-related disappointment occurs when a desired outcome is unexpectedly not obtained. According to Van Dijk and Zeelenberg (2002) individuals that experience this type of disappointment feel empty inside and believe they lost an opportunity. Person-related disappointment occurs "in situation when one attributes the cause of the undesirable situation to another person" (Van Dijk \& Zeelenberg, 2002, p. 800). Individuals that experience person-related disappointment tend to distance themselves from others. They disapprove of the other person's actions and often perceive the situation as one in which they are not responsible for the behaviors of others.

The idea of disappointing one's parents is hardly a novel phenomenon. Fear of disappointing parents can fall under two categories: explicit expectations outlined by one's parents and implicit expectations. Since we did not interview subject's parents we cannot, with any degree of certainty, verify the accuracy of participants' perceptions of parental expectations. However, the truthfulness of its stated, or unstated existence may not be important. If subjects are identifying this as a concern, the actuality of its existence is trumped by the emotional and behavioral responses of its perceived existence.

Carroll, Shepperd, Sweeny, Carlson and Benigno (2007) identify three types of disappointment for others: empathic concern, resource concern, and self-image concern. Empathic concern occurs when one views the other as an extension of self. The personal and the partner experience become confounded. The other shares the emotional response as if it was their own loss. A resource concern occurs when the outcome of others become personal due to an increased demand on material and psychological resources. A self-image concern occurs when another person's performance reflects upon someone else. If a student comes from an impoverished family, the family's concern may be focused around the potential resources garnered by the student (e.g., Participant \#6). On the other hand a student coming from a highly educated family may not feel the pressure of a resource concern but rather feel the pressure to live up to parental achievements (e.g., Participant \#12, Participant \#7). In this study although the socioeconomic family background of participants' differed greatly, feelings of disappointment avoidance were prevalent.

Strong social bonds may allow others to experience emotional responses to another's outcome even when they are not the primary person (e.g., family member, partner) connected to the outcome (Lickel, Schmader, Curtis, Scarnier, \& Amers 2005). Several interviewees expressed a desire to impress or not disappoint teachers with whom they had a personal relationship. These responses underline the importance of the interpersonal relational components of teaching and learning and the implications on student motivation and achievement. Interviewees did not report a fear of disappointing faculty members with which they had no or limited personal interaction.

Terenzini, Pascarella, and Blimling (1999) note that "the most powerful source of influence on student learning appears to be students' interpersonal interactions, whether with peers or faculty" (p. 619). Class participation might be seen as a symbol of a student's attachment to the class and participation may promote group solidarity. However, when students are fearful of these interactions this may manifest in a contraction of energy that depresses sociability (Collins, 1984). 
The reciprocation of participation is integral to the groups' process of building this solidarity. Participants frequently referenced a reticence to participate in class discussions. Fear of peer disapproval was cited as a rationale for their apprehension. These findings can be partially explained by research on communication anxiety and student rapport.

Student communication is influenced by communication apprehension. McCroskey (1982) defines communication apprehension as "an individual's level of fear or anxiety associated with either real or anticipated communication" ( $p$. 127). Students that score high on measures of communication apprehension will self-disclose less and drop classes that require speaking (Daly \& Stafford, 1984).

Although there is a paucity of research investigating empirical connections between individual characteristics and oral classroom participation, Stoeckli (2010) notes that those who are fearful of social evaluation will "avoid self-presentation in the classroom whenever possible because of a fear of negative experiences" (p. 30). According to Stoeckli (2010) social anxiety and self-esteem (inner characteristics of individuals that are not directly accessible by the observer) impact oral participation in the classroom. Negative experiences in relationships with peers can trigger fears of negative experiences and inhibit classroom engagement and participation in the classroom (Buhs, Ladd, \& Herald, 2006).

Weaver and Qi (2005) suggest that student participation involves the risk of being rejected by one's classmates and therefore may produce fearful responses. These fearful responses might be increased by the instructor's power, expertise, and communication style. When students speak, they run the risk of sounding foolish or uninformed and this may result in humiliation or status loss in the classroom. Although the risk of humiliation may be low in their current situation students might draw upon certain memories of themselves or others experiencing humiliation and therefore retreat from discussion. As Weaver and Qi (2005) note, fears weaken students' confidence to contribute to class discussion. In addition "confidence offers the 'social energy' needed to animate the classroom, and a confidence deficit depresses the climate of interaction (Weaver \& Qi, 2005, p. 575). Students may find it safer to remain silent rather than risk rejection in the classroom.

Interviewees reported a fear of "appearing unintelligent to other students" and "concern with how they would appear in the eyes of their classmates". This rationale for nonparticipation in class discussions is supported by past research (Howard \& Henney, 1998; Howard, James, \& Taylor, 2002; Fassinger, 1995). It is acceptable to achieve as long as you don't look like you are overworking yourself. This leaves students wondering how they can be academically successful while simultaneously thriving in the social realm (Jackson, 2010).

Fears of disapproval negatively impacts student confidence that then influences participation. Informal classroom structures develop as "peers define and enforce informal norms associated with classroom-related behaviors"(Weaver \& Qi, 2005, p. 576). Weaver and Qi (2005) note, "even relatively isolated students may not escape the influence of other students, insofar as their behaviors become oriented toward achieving a modicum of acceptance from fellow students" (p. 576). Although Weaver and Qi's (2005) research focused on younger students, we found that this is still concern amongst older students.

The experiences of our interviewees is partially supported by research demonstrating that student experience of the classroom is as much influenced by social and interpersonal processes as it is by intellectual ones (Goodenow, 1992). Concern over the stigma of performing too well in school has been found with elementary school aged boys (Adler, Kless, \& Adler, 1992) and high-school males (Jackson, 2010) There is a general concern to avoid being perceived as too smart by other students. Often times boys will make attempts to conceal their academic talents in order to avoid the negative stigma of performing beyond the recognized level of masculine acceptance (Czopp, Lasane, Sweigard, Bradshaw, \& Hammer 1998). Adler et al., (1992) refer to this as a "ceiling level of effort" (p.177).

We are unaware of studies that have investigated this phenomenon at the graduate school level. Our results support previous findings concern over presentation in the classroom. Interestingly this dynamic is still occurring in graduate school classrooms and still impacting students' purported rates of participation. As much as graduate school professors may espouse the ideals of open classrooms and encourage a diversity of beliefs, opinions, and viewpoints, participants reported a hesitation to participant due to how others would perceive them.

Seemingly, the manifestation of academic motivation is important to consider. As long as peers cannot observe representations of high academic motivation for achievement (e.g., classroom participation) individuals report that fears of disappointing others can be motivating. In other words, participants report efforts to study harder for exams but not increase rates of participation. We must consider the idea that at the "ceiling level of effort" does not simply occur in high school males. Perhaps this trend continues into college, graduate school, and beyond. However, there is also a motivation to not appear unintelligent or unprepared. Participants reported not wanting to be embarrassed when they are called upon and do not know the answer. Herein lies the dilemma. How do students achieve an image of competency (to avoid judgments of ignorance) and simultaneously avoid being perceived as too knowledgeable or caring too much? 


\section{Future Research}

Graduate students' report several instances of learning-related fears. In particular, we think in-class fears regarding peer judgments is a topic worthy of future research-specifically applied classroom based research. What are the implications of classroom cultures where students must constantly toe the middle-line of presenting a competent, but not over competent self-image? What initiatives can graduate school faculty members implement to mitigate fears of peer judgment?

There is ample research demonstrating that positive learning environments enhance student learning. For example, Marzano (1992) found that students learn best when they have positive attitudes and perceptions of the classroom. More specifically, Fassinger (1995) found that student perceptions of peer friendliness and support directly influenced how often they were willing to speak in class. Similarly, Weaver and Qi (2005) found that when students reported fear of peer disapproval it stifled in-class participation. Finally, Dallimore, Hertenstein, and Platt (2008) found that when students perceive their classmates as being confirming and supportive they become more comfortable which in turn increases their likelihood of participating.

Informal conversations with fellow classmates are important in creating a positive school structure (Wambach \& Brothen, 1997). Instructors can help facilitate this process by allowing students the opportunity to build positive relationships with one another in the classroom. In particular, content-free student-to-student engagement creates social learning settings centered on positive interaction (Kagan, 1997). Weaver and Qi (2005) stress the importance of encouraging student-to-student connectedness early in the semester as a means for increasing student involvement throughout the semester.

Although the social-emotional aspects of learning are considered during the early school years the importance of these processes seems to get lost as content becomes more specialized. Perhaps there is an assumption that students have learned the skills necessary to navigate a multitude of educational settings. We need to further investigate techniques to built rapport in the classroom. Research suggests that as rapport is built in the classroom social anxieties are reduced (Coupland, 2003). Certainly strategies used with elementary school children to build rapport may not be applicable to graduate students but the necessity is still there. Only through applied classroom research will we gain a deeper understanding of how students can become more connected in the classroom.

\section{Conclusion}

The affective dimensions of learning are important to consider, regardless of the level of education. The study described here reveals how the contribution of both fears related to disappointing others and peer judgment contributes to a greater understanding of graduate students' learning experiences. Of particular interest to us is the relationship between motivation and fear of disappointing others, as well as the relationship between motivation and fear of peer judgment. The fear of disappointing others emerged as a contributor to academic motivation; conversely a fear of negative peer evaluation seemed to hold students back from participating in classroom discussions. We believe it would be worthwhile for future research to investigate ways to build community in graduate school classrooms that minimize individual fears of peer evaluation that may stifle student engagement.

\section{References}

Adler, P. A., Kless, S. J., \& Adler, P. (1992). Socialization to gender roles: Popularity among elementary boys and girls. Sociology of Education, 65, 169-197.

Barbalet, J. M. (1998). Emotion, social theory and social structure: A macrosociological approach. Cambridge: Cambridge University Press.

Beck, P. W., \& Burns, D. (1979). Anxiety and depression in law students: Cognitive internvention. Journal of Legal

Education, 30, 270-290.

Belanger, J. J., Lafreniere, M. K., Vallerand, R. J., \& Kruglanski, A. W. (2012). Driven by fear: The effect of success and failure information on passionate individuals' performance. Journal of Personality and Social Psychology, 104, 180-195.

Bell, D. E. (1985). Disappointment in decision making under uncertainty. Operations Research, 33, 1-27.

Berkowitz, L., Jaffee, S., Jo, E., \& Troccoli, B. T. (1999). On the correction of feeling- induced judgmental biases. In J. P. Forgas, Feeling and thinking: The role of affect in social cognition an behavior (1st Edition ed.). New York/Cambridge: Cambridge University Press.

Bower, G. H. (1981). Mood and memory. American Psychologist, 36, 129-148. 
Buhs, E. S., Ladd, G. H., \& Herald, S. L. (2006). Peer exclusion and victimization: Processes that mediate the relation between peer group rejection and children's classroom engagment and achievement? Journal of Educational Psychology, 98, 1-13.

Carroll, P. J., Shepperd, J. A., Sweeny, K., Carlson, E., \& Benigno, J. P. (2007). Disappointment for others. Cognition and Emotion, 11, 1565-1576.

Collins, R. (1984). The role of emotion in social structure. In K. R. Scherer, \& P. Ekman, Approaches to emotion (pp. 385-396). Hillsdale, NJ: Lawrence Erlbaum Associates.

Coupland, J. (2003). Small talk: Social functions. Research on Language and Social Interactions, 36, 1-6.

Covington, M. V., \& Omelich, C. L (1979). The double-edged sword in school achievement. Journal of Education Psychology, 71, 169-182.

Covington, M. V., \& Teele, K. (1996). Overcoming student failure: Changing motives and incentives for learning. Washington, DC, US: American Psychological Association. http://dx.doi.org/10.1037/10193-000.

Czopp, A. M., Lasane, T. P., Sweigard, P. N., Bradshaw, S. D., \& Hammer, E. D. (1998). Masculine styles of self-presentation in the classroom: Preceptions of joe cool. Journal of Social Behavior and Personality , 13(2), 281-294.

Dallimore, E. J., Hertenstein, J. H., \& Platt, M. B. (2008). Using discussion pedagogy to enhance oral and written communcation skills. College Teaching, 56(3), 163-172.

Daly, J. A., \& Stafford, L. (1984). Correlates and consequences of social-communicative anxiety. In K. Daly, \& J. McCroskey, Avoiding Communication (pp. 125-144). Beverly Hills, CA: Sage.

Dewey, J. (1984). John Dewey: The later works (Vol. 5). Boydston, J.A. (Ed.) Carbondale, IL: Southern Illinois University Press. (Original work published 1925).

Elkins, J. R. (1985). Rites de Passage: Law students “Telling Their Lives.” Journal of Legal Education, 35(1), 27-55.

Eme, R., \& Lawrence, L. (1976). Fear of success and academic underachievement. Sex Roles, 2(3), 269-271.

English, A., \& Stengel, B. (2010). Exploring fear: Rousseau, Dewey, and Freire on fear and learning. Educational Theory, 60(5), 521-542.

Fassinger, P. A. (1995). Professors' and students' perceptions of why students participate in class. Teaching Sociology, 24, 25-33.

Forgas, J. P., \& Bower, G. H. (1987). Mood effects on person-perception judgments. Journal of Personality and Social Psychology, 53, 53-60.

Fridja, N. H. (1986). The emotions. Cambridge: Cambridge University Press.

Glaser, B. G., \& Strauss, A. L. (1967). The discovery of grounded theory: Strategies for qualitative research. Chicago: Aldine Publishing Company.

Goodenow, C. (1992). Strengthening the links between educational psychology and the study of social contexts. Educational Psychologist, 27, 177-196.

Hess, G, F. (2002). Heads and hearts: The teaching and learning environment in law school. Journal of Legal Education. 52(1-2), 75-111.

Hochschild, A. R. (1983). The managed heart: commercialization of human feelings. Berkeley: University of California Press.

Howard, J. R., \& Henney, A. L. (1998). Student participation and instructor gender in the mixed-age college classroom. Journal of Higher Education, 69, 384-405.

Howard, J. R., James, G. H., \& Taylor, D. R. (2002). The consolidation of responsibilty in the mixed-age college classroom. Teaching Sociology, 30, 214-234.

Isen, A. M. (1993). Positive affect and decision making. In M. Lewis, \& J. M. Haviland, Handbook of Emotions. New York/London: Guilford Press.

Jackson, C. (2010). Fear in education. Educational Review, 62, 39-52.

Kagan, S. (1997). Cooperative learning. San Clemente, CA: Kagan Cooperative Learning.

Larcombe, W., Tumbaga, L., Malkin, I., Nicholson, P., \& Tokatlidis, O. (2013). Does an Improved Experience of Law School Protect Students against Depression, Anxiety and Stress? An Empirical Study of Wellbeing and the Law 
School Experience of LLB and JD programs. The Sydney Law Review, 35, 407-432.

Lickel, B., Schmader, T., Curtis, M., Scarnier, M., \& Ames, D. (2005). Vicarious shame and guilt. Group Processes \& Intergroup Relations, 8, 145-157.

Martin, A. J., (2011). Courage in the classroom: Exploring a new framework predicting academic performance and engagement. School Psychology Quarterly, 26, 145-160.

Martin, A. J., \& Marsh, H. W. (2003). Fear of failure: Friend or foe? Australian Psychologist, 38, 31-38.

Marzano, R. J. (1992). A different kind of classroom: Teaching with dimensions of learning. Alexandria, VA: Association for Supervision and Curriculum.

McCroskey, J. C. (1982). Oral communcaiton apprehension: A reconceptualization. In M. Burgoon, Communication Yearbook (pp. 136-170). Beverly Hills: Sage.

Milton, K. (2002). Loving Nature: Towards an Ecology of Emotion. New York: Routledge.

Ortony, A., Clore, G. L., \& Collins, A. (1988). The Cognitive Structure of Emotions. New York: Cambridge University Press.

Putwain, D. (2008). Examiniation of stress and test anxiety. The Psychologist, 21, 1026-1029.

Putwain, D. (2009). Assessment and examination stress in Key Stage 4. British Educational Research Journal, 35, 391-411.

Rachman, S. (1978). Fear and Courage. San Francisco, CA, US: W.H.Freeman.

Reifman, A., Mcintosh, D. N., \& Ellsworth, P. C. (2000). Depression and affect among law students during law school: A longitudinal study. Journal of Emotional Abuse, 2, 93-107.

Rousseau, J. J. (1979). Emile or On Education. (A. Bloom Trans.). New York NY: Basic Books. (Original work published 1762).

Schimmack, U., \& Diener, E. (1997). Affect intensity: Separating intensity and frequency in repeatedly measured affect. Journal of Personality and Social Psychology, 73, 1313-1329.

Schouwenburg, H. C., (1992). Procrastinators and fear of failure: An exploration of reasons for procrastination. European Journal of Personality, 6, 225-236.

Sprinkle, R., Hunt, S., Simonds, C., \& Comadena, M. (2006). Fear in the classroom: An examination of teacher's use of fear appeals and students learning outcomes. Communication Education, 55, 389-402

Stoeckli, G. (2010). The role of individual and social factors in classroom loneliness. The Journal of Educational Research, 103, 28-39.

Terenzini, P. T., Pascarella, E. T., \& Blimling, G. S. (1999). Students' out-of-class experiences and their influence on learning and cognitive development: A literature review. Journal of College Student Development, 40, 610-623.

Thorne, S. (2008). Interpretive Description. Walnut Creek, CA: Left Coast Press.

Van Dijk, W. W., \& Zeelenberg, M. (2002). What do we talk about when we talk about disappointment? Distinguishing outcome-related disappointment and person related disappointment. Cognition Emotion, 12, 129-148.

Wambach, C., \& Brothen, T. (1997). Teacher self-disclosure and student classroom participation revisited. Teaching of Psycholgoy, 24(4), 262-263.

Weaver, R. R., \& Qi, J. (2005). Classroom organization and participation: College students' perceptions. The Journal of Higher Education, 76(5), 570-601.

Williams, K., Jamieson, F., \& Hollingsworth, S. (2008). "He was a bit of a delicate thing": White middle-class boys, gender, school choice and parental anxiety. Gender and Education, 20, 399-408.

\section{$(\mathrm{cc}) \mathrm{Br}$}

This work is licensed under a Creative Commons Attribution 3.0 License. 